\title{
Effect of on-table extubation after congenital heart surgery on outcomes in a developing country
}

\author{
Zeena Makhija ${ }^{1 *}$, Amit Kumar $^{2}$, Mahesh Bhatt ${ }^{3}$ \\ From World Society of Cardiothoracic Surgeons 25th Anniversary Congress, Edinburgh \\ Edinburgh, UK. 19-22 September 2015
}

\section{Background/Introduction}

Recent advances in anaesthesiology and critical care have made it feasible to extubate children on-table after surgical repair of congenital heart defects.

\section{Aims/Objectives}

We compared two propensity matched groups to evaluate the effect of on-table extubation on outcomes.

\section{Method}

144 patients underwent surgical repair for various congenital heart defects in our institution between February 2014 and April 2015. 34 patients who were extubated on table (group A) were compared with propensity matched group of 34 patients who were extubated later in the ICU(group B). Re-intubation, significant bleeding, low cardiac output syndrome, arrhythmia in PICU, ICU stay, hospital stay and hospital cost were analysed.

\section{Results}

Demographics of both the groups were similar. Mean age at time of operation was $4.1 \pm 3.8$ years. Seventynine percent $(\mathrm{n}=27)$ were $<5$ years old and $70 \%(\mathrm{n}=$ $24)$ were males. Ventricular septal defect $(38 \%, \mathrm{n}=13)$ was the most common lesion, followed by atrial septal defect $(35 \%, \mathrm{n}=12)$ which were repaired. Cardiopulmonary bypass and aortic cross clamp times were $65.3 \pm$ 32.2 and $31.3 \pm 22.8$ minutes, respectively. The mean inotrope score was $2.1 \pm 1.3$. There was no mortality in the cohort and no complications during PICU stay. None of the patients required re-intubation. The mean length of PICU stay was $1.4 \pm 0.8$ days in group A which was not statistically significantly different from group B $(1.8 \pm$

'Department of Congenital Cardiothoracic surgery, Shree Krishna Hospital,

Gujarat, India

Full list of author information is available at the end of the article
0.6 days) (p value: 0.6$)$. The total hospital stay and the hospital cost were also similar in both groups.

\section{Discussion/Conclusion}

On table extubation is safe and feasible in a selected group of patients who undergo congenital heart surgery. It lessens the duration of ICU stay, total hospital stay and hospital expenditure.

\section{Authors' details}

'Department of Congenital Cardiothoracic surgery, Shree Krishna Hospital, Gujarat, India. ${ }^{2}$ Department of Pediatric Cardiac Intensive Care, Shree Krishna Hospital, Gujarat, India. ${ }^{3}$ Department of Pediatric Cardiology, Shree Krishna Hospital, Gujarat, India.

Published: 16 December 2015

doi:10.1186/1749-8090-10-S1-A281

Cite this article as: Makhija et al:: Effect of on-table extubation after congenital heart surgery on outcomes in a developing country. Journal of Cardiothoracic Surgery 2015 10(Suppl 1):A281.

Submit your next manuscript to BioMed Central and take full advantage of:

- Convenient online submission

- Thorough peer review

- No space constraints or color figure charges

- Immediate publication on acceptance

- Inclusion in PubMed, CAS, Scopus and Google Scholar

- Research which is freely available for redistribution 